\title{
Correction to: Epidemiology of Dermatophytes in Belgium: A 5 Years' Survey
}

\author{
Rosalie Sacheli • Lize Cuypers • Laurence Seidel • Rajae Darfouf • \\ Caroline Adjetey $\cdot$ Katrien Lagrou $\cdot$ Marie-Pierre Hayette
}

Published online: 17 September 2021

(C) Springer Nature B.V. 2021

Correction to: Mycopathologia (2021) 186:399-409

https://doi.org/10.1007/s11046-021-00542-4

In the original publication of the article, the authors first and last name were swapped and incorrectly published as "Sacheli Rosalie, Cuypers Lize, Seidel Laurence, Darfouf Rajae, Adjetey Caroline, Lagrou Katrien and Hayette Marie-Pierre".

The correct first and last name of the authors should be "Rosalie Sacheli, Lize Cuypers, Laurence Seidel,
Rajae Darfouf, Caroline Adjetey, Katrien Lagrou and Marie-Pierre Hayette".

The original article has been corrected.

Publisher's Note Springer Nature remains neutral with regard to jurisdictional claims in published maps and institutional affiliations.

The original article can be found online at https:// doi.org/10.1007/s11046-021-00542-4.

R. Sacheli $(\varangle) \cdot$ R. Darfouf · C. Adjetey · M.-P. Hayette Department of Clinical Microbiology, Belgian National Reference Center, University Hospital of Liege, Liège, Belgium

e-mail: R.sacheli@chuliege.be

L. Seidel

Department of Biostatistics, University Hospital of Liege, Liege, Belgium

L. Cuypers · K. Lagrou

Laboratory of Clinical Bacteriology and Mycology,

Belgian National Reference Center, University Hospital

of Leuven, Leuven, Belgium 